\title{
DEFENSE ACCESS TO GRAND JURY TESTIMONY: A RIGHT IN SEARCH OF A STANDARD
}

Although it had been previously recognized that a defendant was entitled to inspect grand jury testimony in certain circumstances, in Dennis v. United States the Supreme Court first granted disclosure on the ground that sufficient "particularized need" had been shown. Although failing to clarify adequately the constituents of this verbal formula or to define fully the procedure to be utilized, the Court nevertheless clearly implied a disposition toward liberal disclosure. In light of the lack of substantive specificity in Dennis, subsequent lower court interpretations have generally emphasized the permissive tenor of the opinion to promulgate rules of automatic disclosure in certain factual situations. These rules, however, differ greatly in scope and rationale. Consequently, the defendant to a federal indictment remains unable to invoke any uniform standard by which his access to a grand jury transcript may be determined. It is arguable that the confusion of the present law may be remedied by providing the defendant with recourse to a standard of disclosure based upon constitutional principles mandating due process in criminal proceedings rather than solely upon judicial discretion.

P erhaps best known for its illiberal interpretation of the Federal Conspiracy Statute, ${ }^{1}$ Dennis v. United States ${ }^{2}$ also marked the first instance in which the Supreme Court identified the requisite "particularized need"3 a defendant must demonstrate to gain access to the grand jury testimony of a witness appearing in a federal trial. Although the Court had previously recognized exceptions to the traditional rule of secrecy for grand

118 U.S.C. $\$ 371$ (1964).

' 384 U.S. 855 (1966), rev'g 346 F.2d 10 (10th Cir. 1965), noted in 52 A.B.A.J. 868 (1966), 80 HARV. L. Rev. 213 (1966), 62 Nw. U.L. Rev. 233 (1967) and 28 U. PrTT. L. Rev. 338 (1966). See also Calkins, The Fading Myth of Grand Jury Secrecy, 1 Jorin Marshall J. Prac. \& Proc. 18, 32-36 (1967). In Dennis the Court upheld convictions of conspiracy to violate $\S 9(\mathrm{~h})$ of the Taft-Hartley Act, ch. 120, $\S 9(\mathrm{~h})$, 61 Stat. 146 (1947) (repealed by 73 Stat. 525 (1959) ), which denied use of the NLRB to unions the officers of which failed to file non-Comnunist affidavits, despite the fact that $\S 9(\mathrm{~h})$ had previously been repealed. The lower court decision was reversed, however, for refusal by the trial judge to permit the defendants to inspeet the grand jury testimony of several government witnesses. See notes 48-68 infra and accompanying text.

${ }^{3}$ The phrase "particularized need" first appeared in United States v. Procter \& Gamble Co., 356 U.S. 677, 683 (1958). See notes 30-40 infra and acompanying text. 
jury minutes" where required by the "ends of justice,"5 or where "particularized need"6 for the requested testimony was established by the defendant, no case had arisen which mandated their application.? Moreover, since the Court had failed to define adequately the attributes of those exceptional situations permitting disclosure, ${ }^{8}$ lower courts, left relatively free to interpret the standards by which their discretion to grant access should be guided, ouly infrequently found that the requirements had been met.9 Judicial reappraisal in liglit of Dennis, ${ }^{10}$ however, indicates a trend toward more liberal disclosure of the grand jury testimony of a witness who has appeared at trial.11 Thus, utilizing the standard of "particularized

${ }^{4}$ The rule of secrecy for grand jury minutes is currently delineated into five policy considerations. See note 19 infra and accompanying text.

${ }^{5}$ See note 21 infra.

${ }^{\circ}$ See note 40 infra.

'In each of the three instances prior to Dennis in which the Supreme Court considered a request for disclosure of grand jury minutes, the Court refused to find a sufficient demonstration of need. Pittsburgh Plate Glass Co. v. United States, 360 U.S. 395 (1959); United States v. Procter \& Gamble Co., 356 U.S. 677 (1958); United States v. Socony-Vacuum Oil Co., 310 U.S. 150 (1940).

${ }^{8}$ See, e.g., United States v. Procter \& Gamble Co., 356 U.S. 677 (1958); note 42 infra and accompanying text.

D See, e.g., Gordan v. United States, 299 F.2d 117 (D.C. Cir.), aff'd after remand, 313 F.2d 582 (D.C. Cir. 1962), cert. denied, 374 U.S. 839 (1963) (trial judge to examine police officer's grand jury testimony and make available to the defense that portion which is inconsistent with officer's trial testimony where officer was sole witness and his testimony was uncorroborated and challenged); Bary v. United States, 292 F.2d 53 (10th Cir. 1961) (trial judge will not examine grand jury testimony in camera where "particularized need" is not shown); United States v. Hernandez, 290 F.2d 86 (2d Cir. 1961) (trial judge must examine in camera the testimony of key government witnesses regardless of whether defendant initially can make affirmative showing of possible inconsistency between grand jury and trial testimony); United States v. Papaioanu, 10 F.R.D. 517 (D. Del. 1950) (no "good cause" shown in defendant's request for pretrial production of entire grand jury transcript so that he could imderstand charges against him).

${ }^{10}$ See notes 77-130 infra and accompanying text.

${ }^{11}$ See, e.g., Allen v. United States, 390 F.2d 476 (D.C. Cir. 1968); National Dairy Prods. Corp. v. United States, 384 F.2d 457 (8th Cir. 1967), cert. denied, 390 U.S. 957 (1968); Worthy v. United States, 383 F.2d 524 (D.C. Cir. 1967); Cargill v. United States, 381 F.2d 849 (10th Cir. 1967); United States v. Youngblood, 379 F.2d 365 (2d cir. 1967). But see Osborne v. United States, 371 F.2d 913 (9th cir.), cert. denied, 387 U.S. 946 (1967); notes 77-80 infra and accompanying text. Where the testimony sought was unrecorded, Dennis has been rendered inapplicable. See, e.g., Welch v. United States, 371 F.2d 287 (10th Cir.), cert. denied, 385 U.S. 957 (1966); Campbell v. United States, 368 F.2d 521 (10th Cir. 1966). Dennis has also been interpreted to compel, as a matter of right, pre-trial discovery of the grand jury testimony given by corporate officers in a criminal antitrnst suit. United States v. Aeroquip Corp., 41 F.R.D. 441 (E.D. Mich. 1966). See also Washington v. American Pipe \& Constr. Co., 41 F.R.D. 59 (S.D. Cal. 1966). 
need," 12 disclosure has been considered necessary where the testimony is sought to impeach, test the credibility, or refresh the memory of a witness at trial; ${ }^{13}$ where the Government has utilized the transcript; ${ }^{14}$ or merely where a defendant seeks the testimony of the trial witness. ${ }^{15}$ Although these decisions based disclosure upon Federal Rule of Criminal Procedure 6(e), ${ }^{10}$ as did Dennis, it might be argued that disclosure of grand jury testimony is, in many situations, necessary to insure that a defendant is afforded constitutionally-compelled procedural protection. ${ }^{17}$

\section{Development of the Rule of Grand Jury Secrecy}

The doctrine of virtual sacrosanctity for grand jury proceedings originated in the famous Earl of Shaftesbury Trial and was based upon the need to protect jurors from the fear of vengeance by the ruler. ${ }^{18}$ Subsequently, additional rationales developed in support of the rule: (1) prevention of escape by those indicted; (2) insurance of uninhibited deliberation by the grand jurors; (3) prevention of subornation of perjury or tampering with the witnesses; (4) encouragement of free disclosure by witnesses; and (5) protection of the innocent accused against whoin no true bill was returned. ${ }^{19}$ Subsequently, however, the rule became qualified rather

${ }^{12}$ See notes 77-136 infra and accompanying test.

${ }^{13}$ Cargill v. United States, 381 F.2d 849, 851 (10th Cir. 1967). See notes 108-117 infra and accompanying text.

${ }^{14}$ National Dairy Prods. Corp. v. United States, 384 F.2d 457, 461 (8th Cir. 1967), cert. denied, 390 U.S. 957 (1968). See notes 118-130 infra and accompanying text.

${ }^{15}$ United States v. Youngblood, 379 F.2d 365 (2d Cir. 1967). See notes 81-93 infra and accompanying text.

${ }^{16}$ FED. R. CRIM. P. 6(e) provides, in part, the following: "Disclosure of matters occurring before the grand jury other than its deliberations ... may be made to the attorneys for the government for use in the performance of their duties. Otherwise a juror, attorney, interpreter, stenographer, operator of a recording device, or any typist who transcribes recorded testimony may disclose matters occurring before the grand jury only when so directed by the court preliminarily to or in connection with a judicial proceeding or when permitted by the court at the request of the defendant upon a showing that grounds may exist for a motion to dismiss the indictment because of matters occurring before the grand jury. No obligation of secrecy may be imposcd upon any person except in accordance with this rule."

${ }^{17}$ See notes 147-165 infra and accompanying text.

18 See Calkins, The Fading Myth of Grand Jury Secrecy, 1 John MarshatL J. Prac. \& Proc. 18, 19 (1967). Jurors feared reprisals if they failed to indict an accused whom the King wished convicted. Conversely, the accused claimed deprivation of a fair trial since the jurors were influenced by their fear of the King. Calkins, Grand Jury Secrecy, 63 Mrch. L. REv. 455, 457-58 (1965).

${ }^{19}$ See, e.g., United States v. Amazon Indus. Cliem. Corp., 55 F.2d 254 (D. Md. 1931). See generally Pittsburgh Plate Glass Co. v. United States, 360 U.S. 395, 405 (1959) (dissenting opinion); 8 J. WrGMORE, EvideNCE $\& 2360$ (McNaughton rev. ed. 
than absolute as many courts recognized that a prosecutor in criminal litigation might have access, in the discretion of the trial judge, to grand jury testimony in order to refresh the memory of a trial witness. ${ }^{20}$ Moreover, it was provided that once the functions of the grand jury terminated, ${ }^{21}$ disclosure might ensue where application of the traditional rule would be inconsistent with the "ends of justice,"22 although this term remained undefined. ${ }^{23}$ Nevertheless, while recognizing that some theoretical situations should compel exercise of the judge's discretion to grant disclosure, the federal courts were extremely reluctant to find such an occasion. ${ }^{24}$ Apparently, this result rested at least in part upon the belief that the accused already possessed sufficient advantage in a criminal proceeding and consequently ought not to receive further benefits at the risk of debilitating the ends achieved by the non-disclosure standard.25 Even the promulga-

1961). It has been contended that the rule of secrecy is inapplicable once a witness has appeared at trial since the reasons for the rule are no longer applicable. See Pittsburgh Plate Glass, supra, at 406-07 (dissenting opinion); United States v. Youngblood, 379 F.2d 365, 370 n.3 (2d Cir. 1967); note 46 infra.

${ }^{20}$ See, e.g., United States v. Rose, 215 F.2d 617 (3d Cir. 1954) (defendant sought his own grand jury testimony).

${ }^{21}$ Once the functions of the grand jury have terminated, there is obviously no possibility that its proceedings will be adversely affected by disclosure.

${ }_{22}^{2}$ In United States v. Socony-Vacuum, Oil Co., 310 U.S. 150 (1940), the defendants were indicted for an alleged violation of the antitrust laws. During the trial, the Government used portions of the grand jury transcript to refresh the nieniory of several witnesses. The defense request for inspection of these segments of the transcript was denied. The Supreme Court concluded that it was not error to allow prosecution use of the transcript to refresh a witness's nuemory nor to deny inspection to the defendant after such use, unless the denial was prejudicial. Id. at 234-35. According to the Court, disclosure "after the grand jury's functions have ended . . . is wholly proper where the ends of justice require it." Id. at 234.

${ }^{23}$ Id. at 233.

${ }^{24}$ See, e.g., United States v. Socony-Vacuum Oil Co., 310 U.S. 150 (1940); accord, Herzog v. United States, 226 F.2d 561 (9th Cir. 1955), aff'd en banc, 235 F.2d 664, cert. denied, 352 U.S. 844 (1956); United States v. Papaioanu, 10 F.R.D. 517 (D. Del. 1950). See generally Calkins, Grand Jury Secrecy, 63 Mich. L. REv. 455 (1965); Sherry, Grand Jury Minutes: The Unreasonable Rule of Secrecy, 48 VA. L. Rev. 668 (1962).

${ }^{25}$ The notion that the defendant possessed an advantage in a criminal proceeding was crystallized in United States v. Garsson, 291 F. 646 (S.D.N.Y. 1923): "[Disclosure of grand jury minutes] is said to lie in [the] discretion [of the trial judge], and perhaps it does, but no judge of this court has granted it, and I hope none ever will. Under our criminal procedure the accused has every advantage. . . . No doubt grand juries err and indictments are calamities to honest nien, but we must work with human beings and we can correct such errors only at too large a price." Id. at 649 (Hand, J.). This admonition was subsequently enuphasized by other courts. See, e.g., United States v. 
tion of rule $6(\mathrm{e})$ of the Federal Rules of Criminal Procedure, allowing disclosure "when so directed by the Court preliminarily to or in connection with a judicial proceeding," 26 failed to enhance the position of the defendant seeking such an inspection. ${ }^{27}$ Given such judicial reticence, the burden of proving "good cause"28 or that disclosure was requircd by "justice"29 was virtually insurmountable. In fact, the defendant's plca to procure his own grand jury testimony for use in his perjury trial was the only circumstance under which inspection was consistently permitted. ${ }^{30}$

In 1958, however, a new biberality regarding disclosure arose with the decision of the Supreme Court in Jencks $v$. United States. ${ }^{31}$ Finding reversible error in denial of a defendant's request for production of pre-trial

Papaioanu, 10 F.R.D. 517, 518 (D. Del. 1950). See generally Calkins, The Fading Myth of Grand Jury Secrecy, 1 John Marshall J. Prac. \& Proc. 18, 23-25 (1967).

Despite Judge Hand's position, however, the Second Circuit in which he sat has been the most liberal in granting disclosure of grand jury testimony. See notes 81-93 infra and accompanying text.

${ }^{26}$ See note 16 supra.

${ }^{27}$ Many pre-Dennis cases held that rule (6(e) merely placed the decision to grant disclosure within the discretion of the trial judge. In the absence of a showing of an abuse of this discretion, denial of a request for inspection was not error. See, e.g., Pittsburgh Plate Glass Co. v. United States, 360 U.S. 395, 396-99 (1959); Herzog v. United States, 226 F.2d 561, 566-67 (9th Cir. 1955), aff'd en banc, 235 F.2d 664, cert. denied, 352 U.S. 844 (1956). In United States v. Procter \& Gamble Co., 356 U.S. 677 (1958), the trial judge invoked the "good cause" criterion of rule 34 of the Federal Rules of Civil Procedure as a standard to govern the granting of disclosure, id. at 683, but failed to mention the discretionary authority permitted under rule $6(\mathrm{e})$. A number of subsequent lower court decisions similarly denied disclosure without reference to rule 6(e). See, e.g., Berry v. United States, 295 F.2d 192 (8th Cir. 1961), cert. denied, 368 U.S. 955 (1962); Bary v. United States, 292 F.2d 53 (10th Cir. 1961); United States v. Coduto, 284 F.2d 464 (7th Cir. 1960), cert. denied, 365 U.S. 881 (1961).

${ }^{28}$ See, e.g., United States v. Procter \& Gamble Co., 356 U.S. 677, 681 (1958); United States v. Papaioanu, 10 F.R.D. 517, 519 (D. Del. 1950). In Papaioanu the defendant sought pre-trial inspection of grand jury transcript, alleging that the witnesses who had testified could not give competent evidence to establish probable cause. Refusing the request, the court stated that "good cause," the "traditional test" to determine whether production should be granted, had not been proven. The court failed, however, to delineate the constituents of "good cause." Id. at 519.

${ }^{29}$ United States v. Socony-Vacuum Oil Co., 310 U.S. 150, 234 (1940). See also Herzog v. United States, 226 F.2d 561, 566 (9th Cir. 1955), aff'd en banc, 235 F.2d 664, cert. denied, 352 U.S. 844 (1956).

${ }^{30}$ See United States v. Rose, 215 F.2d 617 (3d Cir. 1954). In Rose the court held that when a defendant seeks his own grand jury testimony, "disclosure would not subvert any of the reasons traditionally given for the inviolability of grand jury proceedings." Id. at 630 .

${ }^{31} 353$ U.S. 657 (1957). See generally Keeffe, Jinks and Jencks: A Study of Jencks versus United States in Depth, 7 CaTHoLIC U.L. Rev. 91 (1958); Comment, The Aftermath of the Jencks Case, 11 Stan. L. Rev. 297 (1959); Comment, 27 FordHAM L. REv. 244 (1958). 
reports made by a trial witness to government agents, the Court rejected the prevalent notion that a defendant was required to lay a "preliminary foundation of inconsistency" to gain disclosure.32 The Court added, moreover, that the defendant, not the trial judge, should initially inspect the reports since only the defense was suited to ascertain what documents might be useful. ${ }^{33}$ Thus, the trial judge would resolve admissibility after inspection by the defense, but could not himself determine the relevancy of the material sought to the defendant's case. ${ }^{34}$ Unfortunately, the Court did not specify the extent of initial disclosure required under its new rules. Consequently, alarmed that Jencks would allow a defendant unlimited access to confidential government files, ${ }^{35}$ Congress enacted the Jencks Act. ${ }^{36}$ The Act purported to limit the Jencks decision to its facts and

32353 U.S. at 666. A requirement that the defendant show inconsistency prior to gaining inspection of grand jury testimony has been abandoned since the minutes are usually necessary to show the inconsistency. See Pittsburgh Plate Glass Co. v. United States, 360 U.S. 395, 400 (1959) (dictum); Simmons v. United States, 308 F.2d 324, 325 n.2 (2d Cir. 1962). But cf. United States v. Boyance, 329 F.2d 372, 377 (3d Cir. 1964) (defendant must at least show "likelihood, of discrepancies". One commentator observed that "[t]he recent decision in Simmons [supra] may lead to the rule that one should be entitled to an in camera inspection merely upon a showing that the witness testified before the grand jury and that his testimony at trial is material to the prosecution." G. Shadoan, Law and Tactics in Federal Criminal Cases 202 (1964). According to a recent decision in the Second Circuit, a defendant is entitled to direct inspection upon such a showing, subject only to the prosecutor's motion for a protective order. See United States v. Youngblood, 379 F.2d 365 (2d Cir. 1967); notes $106 \& 139$ infra and accompanying text.

${ }^{33} 353$ U.S. at 669 . The rationale supporting inspection by the defense was later applied to grand jury testimony. See Dennis v. United States, 384 U.S. 855 (1966).

${ }^{34}$ When a defendant seeks grand jury testimony for use on cross-examination, a mere showing that the reports relate to the trial testimony of the witness establishes relevancy for the purpose of production and inspection. 353 U.S. at 669.

${ }^{35}$ See S. REP. Nos. 981 \& 569, 85th Cong., 1st Sess. (1957); H. R. REP. No. 700, 85th Cong., 1st Sess. (1957). The Court, perhaps anticipating this reaction, had emphasized that the defendant in Jencks "did not propose any broad or blind fishing expedition" among government documents. 353 U.S. at 667. Nevertheless, Justice Clark's admonition that the Court had afforded the criminal "a Ronuan holiday for rummaging through confidential information as well as vital national secrets," id. at 681-82 (dissenting opinion), became the more accepted analysis 'of the decision.

${ }^{36} 18$ U.S.C. $\$ 3500$ (1964). The Act provides, inter alia:

"(b) After a witness called by the United States has testified on direct examination, the court shall, on the motion of the defendant, order the United States to produce any statement (as hereinafter defined) of the witness in the possession of the United States which relates to the subject matter as to which the witness has testified. If the entire contents ... relate ... the court shall order it to be delivered directly to the defendant for his examination and use.

"(c) If the United States claims that any statenent ordered to be produced ... contains matter which does not relate to the subject matter of the testimony of the witness, the court shall order [delivery of] ... such statement for the inspection of 
provided that the trial judge inspect the report and excise irrelevancies prior to disclosure upon a government claim that the information sought is extraneous to the defendant's case. Recognizing the restrictive intent of Congress, the Supreme Court subsequently narrowed the purport of Jencks to provide that the decision "had nothing to do with grand jury proceedings and its language was not intended to encompass grand jury minutes."37

Following Jencks, the Supreme Court had two occasions upon which to resolve the remaining difficulties regarding the secrecy of grand jury testimony. ${ }^{38}$ Although in neither instance was the denial of disclosure deemed improper, the Court did promulgate, in United States v. Procter \& Gamble Company, ${ }^{39}$ a comprehensive standard upon which a defendant could rely in demanding disclosure of grand jury testimony. According to the Court, "the use of the grand jury transcript at the trial to impeach a witness, to refresh his recollection, to test his credibility and the like ... are cases of particularized need where the secrecy of the proceedings is lifted discretely and limitedly."40 Subsequent attempts by lower courts to apply

the court in camera. Upon such delivery the court shall excise the portions of such statement which do not relate. ... With such material excised, the court shall then direct delivery of such statement to the defendant for his use. ...

....

"(e) The term 'statement', ... means-

"(1) a written statement made by said witness and signed or otherwise adopted or approved by him; or

"(2) a stenographic, mechanical, electrical, or other recording, or a transcription thereof, which is a substantially verbatim recital of an oral statement made by said witness to an agent of the Government and recorded contemporaneously with the making of such oral statement."

${ }^{37}$ Pittsburgh Plate Glass Co. v. United States, 360 U.S. 395, 398 (1959). Critics have noted that there is really no difference with respect to the need for secrecy between grand jury minutes and Jencks-type statements. Thus, the abrupt conclusion that Jencks does not apply to grand jury testimony seems unfounded. See Calkins, Grand Jury Secrecy, 63 Micri. L. REv. 455, 481 (1965); Comment, The Aftermath of the Jencks Case, 11 StAN. L. Rev. 297, 322-23, 326 (1959); Comment, 27 FordhaM L. Rev. 244, 253 (1958); Note, 62 Nw. U.L. Rev. 233, $240-41$ (1967); Note, 34 N.Y.U.L. REv. 606, 607-08 (1959), However, this inconsistency was not resolved in Dennis v. United States, 384 U.S. 855 (1966).

${ }^{38}$ See Pittsburgh Plate Glass Co. v. United States, 360 U.S. 395 (1959); United States v. Procter \& Gamble Co., 356 U.S. 677 (1958). In Pittsburgh Plate Glass the petitioners appealed their conviction under $\S 1$ of the Sherman Act, 15 U.S.C. $\S 1$ (1964), on the ground that they had been denied their right to inspect the grand testimony of an important government witness who had appeared at trial. Affirming, the Supreme Court found that no "particularized need" lad been shown, and further noted that "proof of the conspiracy was overwhelming aside from [the particular witness's] ... testimony." 360 U.S. at 397-98.

${ }^{39} 356$ U.S. 677 (1958).

40 $1 d$. at 683. The constituents of "particularized need," however, were not made clear by the opinion. Although the Court found the "relevancy and usefulness" of the 
the vague standard of "particularized need,"41 however, failed to liberalize further the requirements of disclosure. Rather, these decisions indicated that the grand jury testimony of a trial witness could not be procured absent a showing of "need" greater than the inere intended use of the testimony for the purposes stated in Procter \& Gamble. Consequently, while denial of the defendant's request for disclosure was occasionally considered error, ${ }^{42}$ most courts failed to find the requisite urgency and continued to apply the traditional rule of secrecy. ${ }^{43}$ Unfortunately, none of the courts discussing the standard of "particularized need" attempted to delineate the scope and content of the term beyond the description originally offered by the Supreme Court.

Contemporaneously, however, an ostensibly separate development indicated that the denial of a defendant's request for access to the grand

testimony "sufficiently established," this alone was not enough to gain disclosure. Rather, some showing of "prejudice" or "injustice" was considered necessary. Id. at 682. Finding such characteristics not present in this case, the Court concluded that the requirement of "good cause" under rule 34 of the Federal Rules of Civil Procedure had not been met sufficiently to compel "wholesale discovery" of the grand jury testimony. Id. at 683.

${ }^{41}$ See, e.g., Gordan v. United States, 299 F.2d 117 (D.C. Cir.), affd, 313 F.2d 582 (1962), cert. denied, 374 U.S. 839 (1963); Bary v. United States, 292 F.2d 53 (10th Cir. 1961); United States v. Coduto, 284 F.2d 464 (7th Cir. 1960), cert. denied, 365 U.S. 881 (1961). In Coduto a defendant convicted for narcotics'violations cited as error the trial court's refusal to permit the inspection of the grand jury testimony of a paid informer for the purpose of testing his credibility. Noting that "there was more than ample evidence to substantiate the verdict of the jury," 284 F.2d at 467, the Seventh Circuit held that the trial court was correct in finding that no "particularized need" had been shown, id. at 468.

${ }^{42}$ See, e.g., Gordan v. United States, 299 F.2d 117 (D.C. Cir.), aff'd, 313 F.2d 582 (1962), cert. denied, 374 U.S. 839 (1963); United States v. Hernandez, 290 F.2d 86 (2d Cir. 1961); United States v. Zborowski, 271 F.2d 661 (2d Cir. 1959). In Hernandez the Court of Appeals for the Second Circuit held that when a defendant requests an in camera inspection of the grand jury testimony of a key government witness, failure by the trial court to comply is reversible error. $290 \mathrm{~F} .2 \mathrm{~d}$ at 89 . In Zborowski the same court concluded that "particularized need" had been demonstrated when a crucial government witness admitted to inconsistencies between his trial and grand jury testimonies. 271 F.2d at 665 .

${ }^{43}$ See, e.g., United States v. Boyance, 329 F.2d 372 (3d Cir. 1964). In Boyance the Court of Appeals for the Third Circuit affirmed a refusal to grant the defense inspection of a government agent's grand jury testimony, noting that the circumstantial evidence against the defendant was independently strong, and that the witness whose testimony was sought was subjected to thorough cross-examination. See also Berry v. United States, 295 F.2d 192 (8th Cir. 1961), cert. denied, 368 U.S. 955 (1962) (trial judge did not abuse discretion in refusing to grant an in camera inspection); United States v. Coduto, 284 F.2d 464 (7th Cir. 1960), cert. denied, 365 U.S. 881 (1961). Apparently, the attitude of the courts deviated'little from the view taken in Herzog v. United States, 226 F.2d 561, 566-67 (9th Cir. 1955), aff'd en banc, 235 F.2d 664, cert. denied, 352 U.S. 844 (1956), that only under a very clear showing of need should the rules of secrecy be set aside. 
jury testimony of a witness appearing at trial may have constitutional implications. In Brady v. Maryland ${ }^{44}$ the Supreme Court held that the prosecution's knowing suppression of evidence favorable to the defendant's case was inconsistent with due process..$^{45}$ Although the Court failed to refer to any of the litigation concerning grand jury testimony or to Jencks, an analogy between the situation in Brady and the withholding of grand jury testimony which may contain favorable evidence seems clear. Thus, if the grounds for secrecy are absent in a particular case ${ }^{46}$ there seems to be little discernible difference between the constitutionally impermissible suppression in Brady and the denial of access to grand jury testimony of significance to the defendant. Nevertheless, the imposition of a constitutional proscription in one case and the resort to judicial discretion in the others remains unreconciled. 47

\section{Dennis v. United States}

In Dennis v. United States ${ }^{48}$ the Supreme Court first utilized the standard of "particularized need" to imvalidate the denial of a defendant's request to inspect the grand jury testimony of governnent witnesses appearing at trial. The petitioners had been indicted for alleged violation of the Federal Conspiracy Statute ${ }^{49}$ and at their trial requested the court to allow inspection of the grand jury testimony of four important government witnesses or, alternatively, to have the court inspect the requested portions of the transcript for inconsistencies in testimony between the grand jury and trial proceedings. ${ }^{50}$ Although the petitioners desired to use this testimony for the purpose of impeachment, a justification impliedly compelling under Procter \& Gamble, ${ }^{51}$ both motions were denied by the trial court on the

44373 U.S. 83 (1963).

${ }^{45} \mathrm{Id}$. at 87. See notes $152-62$ infra and accompanying text.

${ }^{46}$ As critics of the rule of secrecy note, once a witness has testified at trial the traditional reasons for secrecy no longer exist. The first-to prevent escape of an accused-and the fifth-to protect the innocent accused who is not indicted-clearly do not apply upon commencement of trial. The second-to insure free deliberation by the jurors-is also inapplicable, for the grand jury duties have ceased and the deliberations and notes of the jurors are not open to inspection at all. The fourth reason-to encourage free disclosure by a witness-is of no force once a witness has appeared at trial, for he is exposed to publicity and his trial testimondy will generally relate to that given before the grand jury. Only if he committed perjury would harm from inspection result, and this revelation is the very reason for whicl inspection is sought. The third reason-to prevent tampering with a witness-is clearly inapplicable once 'the witness has appeared at trial. United States v. Youngblood, 379 F.2d 365, 370 n.3 (2d Cir. 1967); see, e.g., Calkins, Grand Jury Secrecy, 63 Mrch. L. Rev. 455, 460-65 (1965).

${ }_{47}$ See notes 147-65 infra and accoinpanying text.

48384 U.S. 855 (1966), rev'g 346 F.2d 10 (10th Cir. 1965).

4918 U.S.C. $\$ 371$ (1964). See note 2 supra.

${ }^{50} 384$ U.S. at 868.

${ }^{51}$ See notes $39-40$ supra and accompanying text. 
ground that no "particularized need" was shown. 52 The Court of Appeals affirmed. ${ }^{53}$

Reversing, the Supreme Court recognized the "long established policy" underlying the supression of grand jury proceedings in federal forums, ${ }^{54}$ but emphasized that the consequent rule of non-disclosure was not unqualified. Echoing Procter \& Gable, the Court reiterated that the standard of "particularized need" envisioned as permissible the use of grand jury testimony to test the credibility of a witness at trial, to impeach him, or to refresh his memory. ${ }^{55}$ Noting the Government's concession that need for secrecy in the instant case was minimal, ${ }^{56}$ the Court concluded that the defense had not failed to demonstrate the requisite "need"57 and delineated five factors compelling disclosure: (1) the time lag between the grand jury testimony and the trial; (2) the importance of the witnesses' testimony to the Government's case; (3) the fact that the witnesses' testimony was largely uncorroborated; (4) the accomplice-informant status of the witnesses; and (5) the admission by one of the witnesses that he had erred in earlier statements concerning significant dates.58 Given these circumstances, the "particularized need" was deemed "substantially beyond the minimum required by Rule 6(e) and the prior decisions of this Court."

E2 See Dennis v. United States, 346 F.2d 10 (10th Cir. 1965). Apparently, in view of the other testimony at the trial, no inconsistency between the trial and grand jury testimony of the witness would have been revealed. Id. at 18 .

${ }^{53}$ Dennis v. United States, 346 F.2d 10 (10th Cir. 1965).

54384 U.S. at 869, quoting United States v. Procter \& Gamble Co., 356 U.S. 677, 681 (1958).

55 384 U.S. at 870; see note 40 supra and accompanying text. The Court did not, however, conclusively determine whether any one of the enumerated "cases of particularized need" entitles a defendant, in every instance, to disclosure of related testimony as a matter of right. This nncertainty existed prior to Dennis, see Bary v. United States, 292 F.2d 53 (10th Cir. 1961) (disclosure denied, though testimony sought for impeachment purposes), and apparently remains a source of confusion, see Osborne v. United States, 371 F.2d 913 (9th Cir.), cert. denied, 387 U.S. 946 (1967) (disclosure denied, though testimoney sought for impeachment purposes); notes 77-80 infra and accoinpanying test.

${ }^{60} 384$ U.S. at 869 . The concession by the Government that the need for secrecy in the instant case was minimal excluded the "state secret" objection to disclosure.

${ }^{57} \mathrm{Id}$. at $871-72$.

${ }^{58} I d$. at 872-73. It has been contended that because these factors, with the exception of the fifth-admission of earlier error by the witness-are generally present in all criminal proceedings, the standard of "particularized need" has been largely eviscerated by Dennis. See Note, 28 U. PITT. L. REv. 338, 341-42 (1966). This generality, however, does not appear to be wholly warranted in light of the post-Dennis decisions. See, e.g., United States v. Youngblood, 379 F.2d 365 (2d Cir. 1967); Osborne v. United States, 371 F.2d 913 (9th Cir.), cert. denied, 387 U.S. 946 (1967).

59 384 U.S. at 872; see note 16 supra. The "need" demonstrated in Dennis has been characterized both as "overwhelming," see Note, 62 Nw. U.L. REv. 233, 238 -39 n.30 (1967), and as no more than "tenuous," see Note, 28 U. PITr. L. REv. 338, 
The Court failed, however, to define the constituents of the acceptable "minimum" and, if the five factors were to be representative of that standard, failed to provide guidance as to the relative weight to be given each or to indicate whether the absence of any or all of the factors would be determinative. ${ }^{60}$ Although the consequent obscurity may have resulted from a desire to avoid rigid rules governing the exercise of the trial judge's discretion, the requirement of "particularized need" remained without sufficient substance to make its application in a particular case the subject of reliable prediction. Thus, while it was clear that the Court viewed disclosure expansively and that the specified factors could be utilized to invoke rule $6(\mathrm{e})$, development of a consistent approach to disclosure remained for the lower courts.

As indicating a modern trend toward liberal disclosure, the Court cited the Jencks Act ${ }^{61}$ and emphasized that the proper administration of criminal justice necessitated revelation of relevant information. ${ }^{62}$ Unlike the Jencks Act, lowever, the Dennis decision was unclear regarding the procedure through which a court was to make testimony available to the defendant.63 Apparently rejecting the procedure allowing a defendant, as a matter of

341-42 (1966). The latter view apparently rests on the assumption that since the five factors cited by the Court in Dennis were so general as to be present in most cases, the standard of "particularized need" was largely diluted. See note 58 supra and accompanying text.

${ }^{\circ 0}$ The language and tenor of the Dennis opinion indicates that all five factors need not be present to establish "particularized need". See 384 U.S. at 868-75. However, the Court failed to indicate the comparative importance ascribable to each factor listed. See Note, 62 Nw. U. L. REv. 233, 236 (1967). It has been argued, however, that despite the Court's failure to indicate if all or only a few of the factors need be present, the facts that the witnesses' testimony was uncorroborated, and the crucial importance of the testimony to the Government's case, established a sufficient showing of need. Id. But cf. United States v. Youngblood, 379 F.2d 365 (2d Cir. 1967); Osborne v. United States, 371 F.2d 913 (9th Cir.), cert. denied, 387 U.S. 946 (1967). 61384 U.S. at 871. But cf. notes 36-38 supra and accompanying text.

${ }^{62}$ The Court stated emphatically that: "In our adversary system for determining guilt or innocence, it is rarely justifiable for the prosecution to have exclusive access to a storehouse of relevant fact. Exceptions to this are justifiable only by the clearest and most compelling considerations." 384 U.S. at 873. Two points are worth noting in this statement: (1) The Court eight years earlier had discarded "relevancy" and "usefulness" as insufficient to establish the requisite need to gain disclosure. United States v. Procter \& Gamble Co., 356 U.S. 677, 682 (1958); (2) This seems to be a reversal of the position taken in Procter \& Gamble that the " indispensable secrecy of grand jury proceedings' . . . must not be broken except where there is a compelling necessity." Id. The difference in einphasis may be explained by the difference in facts, but it appears that the Court in Dennis made a conscious attempt to use language almost parallel to that in Procter \& Gamble. The use of such language may bo indicative of the Court's attempt to broaden the application of rule 6(e) of the Federal Rules of Criminal Procedure.

${ }^{63} \mathrm{See} 384$ U.S. at 874. 
right, to demand an in camera inspection, ${ }^{64}$ the Court further provided that a judge should not be required to inspect the entire transcript and present the defense with portions revealing inconsistencies since this procedure would impose too great a burden upon trial courts. ${ }^{65}$ Rather, observing that only an advocate can determine that which is proper and useful to the defendant's case, the Court deemed the role of a trial judge properly "limited to deciding whether a case has been made for production, and to supervise this process: for example, to cause the elimination of extraneous matter ...."66 Arguably, this statement implies that a defendant has a right to complete disclosure of a trial witness's grand jury testimony upon a proper showing of "need," subject only to a governmental claim of privilege for secret information. ${ }^{67}$ However, the Court failed to define precisely the content of the phrase "to cause the elimination of extraneous matter." In light of the Court's determination that the defense is best suited to inspect the transcript and should, upon a showing of "need," be granted disclosure, there does not appear to be any place for an in camera proceeding. But if no in camera inspection occurs upon a demonstration of "need," there is no apparent reason for a discussion of the trial judge's role, for, in the absence of a motion for a protective order, it would be limited merely to ordering disclosure. 68

of Id. In the Second Circuit, prior to the rule announced in United States v. Youngblood, 379 F.2d 365 (2d Cir. 1967), a defendant was entitled as a matter of right to an in camera inspection of the grand jury testimony of a witness who had testified at trial. If the judge found any inconsistencies, he was to disclose the inconsistent portions to the defendant. Id. at 368-69. Youngblood altered this procedure shightly after the Dennis criticism, providing that if a defendant could show "particularized need," he was entitled to inspect the minutes without the in camera inspection. Id. at 369.

${ }^{65} 384$ U.S. at 87475 . Dennis consequently indicates the Court's acceptance of Justice Brennan's argument in Pittsburgh Plate Glass Co. v. United States, 360 U.S. 395 (1959), that "the defense alone can determine the pertinence of the material sought to its case" Id. at 409 (dissenting opinion). See generally Calkins, The Fading Myth of Grand Jury Secrecy, 1 John Marshall J. PRAC. \& Proc. 18, 29-30 (1967).

${ }^{00} 384$ U.S. at 875.

${ }^{67}$ See 384 U.S. at 875 . The state secret privilege is recognized in all circuits which have had occasion to interpret Dennis. See note 139 infra and accompanying text.

${ }^{\text {es }}$ It has been noted that an inconsistency is raised by the Court's failure to explain the precise import of the phrase "eliminate extraneous matter" in light of its determination that the judge should not assume the role of an advocate. See Note, 62 Nw. U.L. REv. 233, 243 (1967). This same commentator is unable to resolve the inconsistency, but believes that in light of the language of the Court, "the initial burden of determining relevancy [is placed] on the trial judge." Id. Nonetheless, this view is subject to the argument that Dennis, in rejecting in camera procedure on the ground that it placed too great a burden on the judge, sought to place the burden of showing relevancy on the defendant. 
In relying entirely upon the judicially prescribed Federal Rules of Criminal Procedure, which place disclosure at the discretion of the trial judge, ${ }^{69}$ the Court may have been attempting to avoid the constitutional overtones concerning due process which have haunted the decision in Jencks. ${ }^{70}$ It may be questioned, however, whether the constitutional issue was wholly submerged smce the Court observed that "[i]n our adversary system for determining guilt or innocence, it is rarely justifiable for the prosecution to have exclusive access to a storehouse of relevant fact."71 This statement, in light of the rationale of Brady $v$. Maryland, ${ }^{72}$ may indicate that denying access to the grand jury testimony of a trial witness is inconsistent with procedural guarantees of the Constitution. Although the material sought in Brady was not grand jury testimony, it is nevertheless arguable that the prohibition against governmental withholding of material which might prove beneficial to a defendant's case should apply to the grand jury transcript. ${ }^{73}$

${ }^{69}$ FED. R. CRIM. P. 6(e). See generally Calkins, The Fading Myth of Grand Jury Secrecy, 1 John Marshall J. Prac. \& Proc. 18, 33-34 (1967); Note, 62 Nw. U.L. REv. 233, 241-42 (1967).

${ }^{70}$ See Keeffe, supra note 31. Keeffe concludes that the Jencks decision rests upon the due process clause of the fifth amendment, although he fails to explain fully how that characterization may be substantiated. Id. at 91,92 . While the Supreme Court did not claim a constitutional basis for its decision, it nevertheless has been elsewhere contended that Jencks may have constitutional implications. See Comment, The Jencks Legislation: The Status of the Accused's Federal Discovery Rights, 38 TEXAs L. REv. 595, 608-11 (1960) [hereinafter cited as Comment, 38 Texas L. Rev. 595 (1960)]. The argument is that since one element of a fair trial is the right of confrontation provided by the sixth amendment, see Pointer v. Texas, 380 U.S. 400, 403 (1965); Note, 44 N.C.L. REv. 173 (1965), denying the defendant the opportunity to confront effectively an adverse witness through the use of pretrial statements of impeachment value is inconsistent with the due process guaranteed by the fifth amendment. Comment, 38 TEXAs L. REv. 595, 608-10 (1960). Yet, since the defendant cannot ascertain the impeachment value of statements not within the statute until he has seen them, and the 'disclosure is in the trial judge's discretion, the constitutional argument might fall because of the defendant's want of standing. See id. at 610-11. See also notes 147-51 infra and accompanying text. In Jencks, however, the Court recognized that the defendant is not required to demonstrate inconsistencies in order to compel disclosure, and it would appear that this provision would apply to statements outside the Jencks Act as well. See 353 U.S. at 666. See also Pittsburgh Plate Glass Co. v. United States, 360 U.S. 395, 400-01 (1959).

71384 U.S. at 873.

72373 U.S. 83 (1963).

${ }^{73}$ The traditional rule of secrecy for grand jury proceedings has received intensive criticism. See generally Calkins, The Fading Myth of Grand Jury Secrecy, 1 JoHN Marshall J. Prac. \& Proc. 18 (1967); Calkins, Grand Jury Secrecy, 63 Mich. L. REv. 455 (1965); Goldstein, The State and the Accused: Balance of Advantage in Criminal Procedure, 69 YALE L.J. 1149 (1960); Sherry, Grand Jury Minutes: The Unreasonable Rule of Secrecy, 48 VA. L. Rev. 668 (1962); Traynor, Ground Lost 
Thus, while Dennis marked a liberal change in the Supreme Court's view of grand jury secrecy, ${ }^{74}$ the decision left several crucial problems for future resolution: (1) determining the definition and role of "particularized need" in obtaining disclosure of the grand jury transcript; (2) defining explicitly the role of the trial judge upon a motion for disclosure; and (3) resolving the constitutional issue involved in granting or denying inspection of the grand jury testimony of a trial witness.

\section{The Progeny of Dennis v. United States}

Although the immediate effect of Dennis was merely to reiterate the standard of "particularized need" and illustrate an example of its application without attempting to delineate the substantive constituents of the term, ${ }^{75}$ the decision did emphasize a uniquely permissive approach to disclosure of grand jury testimony. In this light, the significant decisions interpreting Dennis have taken varying positions both as to the ineaning of that case and the proper scope of allowable disclosure. Thus, on one hand Dennis has been considered to govern completely the scope of disclosure while on the other the significance of the standard utilized has been largely eviscerated. 76

Clearly the most restrictive interpretation of Dennis is that promulgated by the Court of Appeals for the Ninth Circuit in Osborne v. United States.77 Accepting the narrow holding of Dennis, the court compared the facts of that decision to those before it and concluded that none of the five factors utilized by the Supreme Court to demonstrate "particularized need" were present.78 Considering the presence of these factors essential to the establishment of sufficient "need," the court consequently affirmed the denial of the defendant's request for inspection. The court failed, however, to indicate whether the result would have differed had some of the factors been evident. Although Osborne may be sound as a hteral interpretation of Dennis, the decision appears unjustified in discarding the obvious expansive

and Found in Criminal Discovery, 39 N.Y.U.L. REv. 228 (1964); Note, Disclosure of Grand Jury Minutes to Challenge Indictments and Impeach Witnesses in Federal Criminal Cases, 111 U. PA. L. REv. 1154, 1182-94 (1963); Comment, 27 FordHAM L. Rev. 244 (1958). See also Cargill v. United States, 381 F.2d 849 (10th Cir. 1967); United States v. Youngblood, 379 F.2d 365 (2d Cir. 1967). For an analysis of the inapplicability of the reasons for secrecy once the witness has testified at trial see note 46 supra.

74 Calkins, The Fading Myth of Grand Jury Secrecy, 1 JoHN MARShaLI J. PRAC. \& Proc. 18, 32 (1967). Calkins sees the Dennis decision as taking a "pragmatic approach to the scope and intended purposes of the doctrine [of grand jury secrecy]." Id.

${ }^{75}$ See notes 58-60 supra and accompanying text.

${ }^{70}$ Compare Osborne v. United States, 371 F.2d 913 (9th Cir.), cert. denied, 387 U.S. 946 (1967), with United States v. Youngblood, 379 F.2d 365 (2d Cir. 1967).

77371 F.2d 913 (9th Cir.), cert. denied, 387 U.S. 946 (1967).

${ }^{78} \mathrm{Id}$. at 919. 
spirit adopted by the Supreme Court, for there is no indication in the Dennis opinion that the factors there isolated must necessarily exist in all cases of disclosure..$^{79}$ Moreover, the effect of this decision is to imply that the standard of rule $6(\mathrm{e})$ may be met only by the establishment of each of these elements, a representation clearly imconsistent with the Suprene Court's characterization of the "need" shown in Dennis as "substantially beyond the minimum required" by that rule. 80

At the opposite end of the spectrum lies the decision of the Court of Appeals for the Second Circuit in United States v. Youngblood. ${ }^{81}$ Disposing of the specific case before it on a rationale similar to that in Osborne, the court affirmed demial of a motion for disclosure on the ground that only two of the five clements constituting "particularized need" as defined by Dennis were present, thus implying that it considered that standard satisfied only if all five factors were present. ${ }^{82}$ However, the court then undertook to re-examine its practice with regard to disclosure apart from the standards of Dennis. ${ }^{83}$ Viewing Procter \& Gamble, ${ }^{84}$ Pittsburgh Plate Glass, ${ }^{85}$ and Dennis as providing that disclosure is not compelled absent proof of "particularized need," the court refused to construe these cases to permit access only when that criteria is met. ${ }^{86}$ Rather, the court concluded that the specified factors present only a "minimum standard" and fail to "limit the court's power to order disclosure in additional situations where a showing of particularized need has not been made." ${ }^{\prime 87}$ Referring to Dennis further only

${ }^{79}$ See Dennis v. United States, 384 U.S. $855,868-75$ (1966); note 60 supra and acconpanying text. The problem :raised by the silence of the Court as to the relative weight to be ascribed each of the five factors is noted in 62 Nw. U.L. REv. 233, 236 (1967). Examining pre-Dennis decisions in order to determine which of the factors is deemed most critical by the lower courts in exercising their discretion under rule $6(\mathrm{e})$, the author concludes that where "the success of the government's case rested inainly on testimony which was both uncorroborated and of doubtful credibilty . . . the presence of these [two] factors alone would seem to be a sufficient basis for an examination ...." Id. at 238. In light of the more liberal post-Dennis deicsions, however, it appears that it is not the specific need of the defendant which is critical, but rather the general purpose for which the transcript is' to be used.

80384 U.S. at 872.

81379 F.2d 365 (2d Cir. 1967).

${ }^{82}$ The factors which the court considered to be present were: (1) that the testimony sought was that of the key government witness; and (2) that witness's testimony was partially uncorroborated. Id. at 368. However, the court viewed the defense as one which "strains credulity." $I d$.

${ }^{83} \mathrm{Id}$. at 369-70.

84 United States v. Procter \& Gamble Co., 356 U.S. 677 (1958). See notes 39-40 supra and accompanying text.

${ }^{85}$ Pittsburgh Plate Glass Co. v. United States, 360 U.S. 395 (1959). See note 38 supra and acconipanying text.

${ }^{86} 379$ F.2d at 369.

${ }^{87} \mathrm{ld}$. 
to note its emphasis upon liberal disclosure, ${ }^{88}$ the court exercised its discretionary power to require that in future litigation the defendant be entitled as a matter of right, upon request, to inspect those portions of the grand jury transcript relating to the testimony of a trial witness regardless of "particularized need." 89 Although the court initially stressed the absence of the traditional reasons for secrecy where the transcript is desired for impeachment purposes, ${ }^{90}$ the rule as ultimately frauned does not appear limited to that use but apparently attaches merely upon the witness' testimony at trial..$^{91}$

Thus, Youngblood promulgates a bifurcated approach to disclosure: if "particularized need" is demonstrated by the presence of the requisite elements, disclosure is coinpelled, but that standard is not a requirement for access and if not fulfilled, the discretion of the trial judge remains determinative. Moreover, in providing that disclosure is automatically available in a broad area, the court in effcct utilizes the liberal spirit of Dennis to remove the inpediments to the establishment of "particularized need." Consequently, Youngblood limits the significance of Dennis by restricting the applicability of the case to its facts and largely rendering irrelevant the type of inquiry there utilized. Although Youngblood arguably may be inconsistent with Dennis given the Supreme Court's reliance upon "particularized need" as the appropriate standard, the Court did not expressly mandate use of that requirement in determining disclosure..$^{22}$ On the other liand, Youngblood is not only clearly compatible

${ }^{88} \mathrm{Id}$.

${ }^{89}$ Id. at 370. The court concluded "that a defendant should be entitled to see all the grand jury testimony of each witness on the subjects about which that witness testified at the defendant's trial." $I d$.

${ }^{20} \mathrm{Id}$. at 369-70. Considering each of the five reasons usually presented to justify secrecy, see United States v. Procter \& Gamble Co., 356 U.S. 677, $681-82$ n.6 (1958); note 19 supra and accompanying text, the court expressly found all to be inapplicable once the witness had appeared at trial. 379 F.2d at 370 n.3. See note 46 supra.

${ }^{01}$ See 379 F.2d at 370.

${ }^{92}$ See Dennis v. United States, 384 U.S. $855,869-74$ (1966). The Court initially observed that under rule $6(\mathrm{e})$ the trial judge had discretionary power to grant disclosure. Id. at 869-70. The opinion then noted that in Pittsburgh Plate Glass "the entire Court was agreed that upon a showing of 'partcularized need' defense counsel might have access to relevant portions of the grand jury testimony of a trial witness ...." Id. at 870 , and concluded that under the circumstances of Dennis the need shown by the defendants went "substantially beyond" the minimum required by rule $6(\mathrm{e}), \mathrm{Id}$. at 872. Thus, disclosure was inandated. $I d$. at 875 . The opinion did not expressly state that a showing of "particularized need" was essential to the exercise of a trial judge's discretion under rule 6(e), although its reference to Pittsburgh Plate Glass may have indicated that such a showing was essential in the past. Under Dennis, then, a denonstration jof "particularized need" eliminates the discretion of the trial judge to deny disclosure. Nonetheless, Dennis reliance on rule $6(\mathrm{e})$ indicates that there is still a discretionary power in a trial judge to deny disclosure. If the rule is to be given 
with liberal disclosure but commendably resolves the ambiguity of Dennis ${ }^{93}$ to provide a viable rule of access unencumbered by pedantic adherence to the traditional policy of secrecy.

Comparable in liberality, although varying in rationale, is the decision of the Court of Appeals for the District of Columbia Circuit in Allen v. United States. ${ }^{94}$ Noting the adinonition in Dennis that disclosure best promotes the proper administration of criminal justice, ${ }^{95}$ the court refused to require a manifestation of "particularized need" in the absence of demonstrated urgency for secrecy. ${ }^{96}$ Rather, it empliasized that non-disclosure is acceptable only in the most compelling circumstances and concluded that Dennis inade clear that the traditional argunents for secrecy were inapplicable when the witness had testified at trial.97 The court went on, however, to reject the breadth of disclosure allowable in Youngblood on the ground that permitting disclosure in every instance might negate valid reasons for secrecy and would often cause unnecessary delay in the trial.98 Rather, repudiating the standard of "particularized need" as obstruetive of useful discovery, the court held that in each case the factual context should govern and the defendant must establish only a "semblance of need" as a "threshold" requirement in order to insure against the evils of automatic

substantive effect, it seems that a discretionary denial of disclosure would be proper when the defendant failed to show "particularized need." In short, the Dennis decision arguably removed the discretionary power of the judge to deny disclosure upon a demonstration of "particularized need," thereby inferentially holding that "need" would no longer be a requirement for disclosure, for in the absence of a showing of need, the trial judge, in his discretion, might still grant inspection under rule $6(\mathrm{e})$. The Youngblood court accepts this reason as the basis for its independent ruling. See notes 87-89 supra and accompanying text.

${ }^{93}$ See notes 58-60 supra and accompanying text.

os 390 F.2d 476 (D.C. Cir. 1968). The defendant had been convicted of assault and unauthorized use of a motor vehicle entirely on the testimony of a police officer whose account of the incident relating to the arrest and alleged subsequent oral confession were challenged both by the defendant and his witness. The defendant's motion for production of the officer's grand jury testimony was denied when the five factors found compelling in Dennis were not established. 390 F.2d at 480.

${ }^{95} \mathrm{Id}$. at 481, quoting Dennis v. United States, 384 U.S. 855, 870 (1966).

${ }^{\circ 6} 390$ F.2d at 482 . The court indicated that "the mere fact that a witness' prior testimony was given to grand jurors is not a clear and compelling reason to immunize it from later scrutiny after he has given testimony on the same subject at trial." $I d$. at $480-81$.

${ }^{97} I d$. The recognition that disclosure should be granted unless a compelling need for secrecy is shown reverses the position initially adopted by the Supreme Court iu United States v. Procter \& Gamble Co., 356 U.S. 677 (1958), that the rule of secrecy "must not be broken except where there is a compelling necessity" for disclosure. Id. at 682.

${ }^{\circ 8} 390$ F.2d at $481-82$. 
disclosure.99 Once this "need" is manifested, the burden of persuasion apparently shifts to the prosecution. ${ }^{100}$ Moreover, the court considered the factors enumerated in Dennis to be merely exemplary of circumstances showing "need" and thus not indispensable.101 Finding no valid reason for secrecy in the case before it, the court announced a per se rule that the defendant had shown sufficient "need" for the grand jury testimony of a policeman who had testified in relation to a confession. ${ }^{102}$

Clearly more permissive than Dennis, Allen arguably extends beyond Youngblood as well. Although a formalistic impediment to disclosure is retaimed in the requirement that some form of "need" be shown, the substance of this standard is apparently minimal. Moreover, the District of Columbia Circuit indicates, unlike Dennis or Youngblood, that in some cases access may be compelled by pre-trial inotion. ${ }^{103}$ On the other hand, there is little assurance that a prerequisite of a "seinblance of need" will be any less obfuscatory in application than that of "particularized need." Consequently, the rule of automatic disclosure promulgated in Youngblood may represent the perferable resolution with regard to facility of administration.

Allen differs significantly froin Youngblood, however, in the manner in which the court utilizes Dennis to rationalize its position. While only the liberal tenor of Dennis is noted in support of the ultimate conclusion in

${ }^{80} 7 d$.

${ }^{100}$ See Id. By lessening the showing of need necessary to compel disclosure, the court apparently sought to place only a slight burden on the defendant. In effect, the approach is to shift the issue from whether the defendant should see the material in question to whether the material should be kept from the defendant. While it is still incumbent upon the defendant to establish some need, the practical result of lowering the "threshold" requirement is to effectuate a presumption favoring disclosure.

${ }^{101}$ Id. at 482.

${ }^{102}$ Id. As indicated in Dennis v. United States, 384 U.S. 855, 875 (1966), and later determined in United States v. Youngblood, 379 F.2d 365, 370 (2d Cir. 1967), and Cargill v. United States, 381 F.2d 849, 852 (10th Cir. 1967), the Allen court agreed that part, or all, of the testimony could be suppressed on the basis of a proper motion for a protective order by the government. 390 F.2d at 482 .

${ }^{103} 390$ F.2d at 482 n.16: "Indeed, unless the prosecutor represents that there is substantial doubt whether the officer will testify at trial, we see no good reason why the grand jury testimony should not be available through a pre-trial motion." However, the court referred solely to the situation in which a police officer testified in relation to a confession by the defendant: "In the less usual case of a witness to a confession who is not a police officer there may be more reason to defer production, because of fear of tampering, and desire to encourage witnesses to testify before the grand jury." Id. In light of the latter observation by the court, it would seem that pretrial discovery will remain more difficult to obtain than discovery after the witness has testified since the traditional reasons for secrecy are considered of more efficacy in the pre-trial stage. 
Youngblood, ${ }^{104}$ Allen purports to interpret Dennis rather than distinguish it, and finds in that decision both a restriction upon the role of secrecy and an overriding deinand for the fullest possible disclosure. ${ }^{105}$ Stressing these aspects, the court reads Dennis as a departure from the traditional restrictive notions of "particularized need" toward a flexible contextual consideration. Thus, Allen is arguably inore consistent with Dennis since it basically accepts the rationale of that descision as governing the scope of grand jury transcript disclosure. On the other hand, both Allen and Youngblood reject the "particularized need" standard expressly relied upon by the Supreme Court. ${ }^{106}$

Conversely, two courts have retained the standard of "particularized need," as in Osborne, ${ }^{107}$ but broadened the scope of available disclosure by propounding liberal definitions of the phrase. Thus, in Cargill v. United States ${ }^{108}$ the Court of Appeals for the Tenth Circuit held that where the grand jury transcript is requested for the purpose of impeaching a witness, testing his credibility, or refreshing his memory, "particularized need" is shown and no additional facts need be demonstrated. ${ }^{109}$ The Tenth Circuit concluded that the Dennis Court had "in effect" provided that access is always available in these circumstances and thus, with regard to cross-examination, had rejected the substance of the "particularized need"

${ }^{104} 379$ F.2d 365, 369-70 (2d Cir. 1967).

${ }^{105}$ The court considered the ultimate question in Dennis and in the case at bar to be "whether the 'clearest and most compelling considerations' dictate that the grand jury testimony ... in contradistinction to other evidence the government might bave, be kept from the defendant," 390 F.2d at 480 , and found Dennis to make it "clear ... that when the request for disclosure is made by a criminal defendant who has already been indicted and when the request is for the prior testimony of a witness who has already testified at trial, 'none of the reasons traditionally advanced to justify nondisclosure ... are significant." "Id. at 481.

${ }^{106}$ Youngblood discarded "particularized need" entirely, holding that once a witness has testified at trial the defendant is entitled, as a matter of right, to the witness's grand jury testimony. 379 F. 2 d at 369-70, while Allen noted that the "particularized need" requirement was too stringent, and held that a lesser, though still undefined, "semblance of need" standard was to be applied in the District of Columbia Circuit. $390 \mathrm{~F} .2 \mathrm{~d}$ at 482.

${ }^{107}$ Osborne v. United States, 371 F.2d 913 (9th Cir.) cert. denied, 387 U.S. 946 (1967). See notes 77-80 supra and accompanying text.

108381 F. 2d 849 (10th Cir. 1967). Convicted of perjury, the defendant in Cargill claimed on appeal that the trial court had erred in refusing to allow him to inspect the grand jury testimony of a government witness for possible use in cross-examination. Upon the trial court's refusal to grant direct inspection, he sought and was granted an in camera inspection of the grand jury transcript. When the trial judge concluded that nothing of importance was contained in the transcript and refused to disclose the requested portion, the defendant appealed his conviction. Id. at 850-51.

${ }^{109}$ Id. at 852-53. The Cargill view appears logically more consistent with the rationale of Dennis than does that of Youngblood, which totally discards the standard of "particularized need." See note 106 supra. 
requirement while retaining merely its form.110 Consequently, Cargill accepted the Dennis standard but, unlike Osborne, provided a rule of automatic disclosure which disregards the five factors enumerated in the Dennis opinion. Thus, the Tenth Circuit effectuates in substance the ultimate rule in Youngblood, although more narrowly delimited since it is applicable only within the confines of cross-examination.111 Moreover, the court considers the efficacy of Dennis to be restricted to the three enumerated uses of the grand jury testimony. ${ }^{112}$ It is unclear from the opinion whether the court would thus conclude that disclosure is unavailable in other circumstances or merely that where a different use of the transcript is intended the defendant would be required to present a formal demonstration of "particularized need." If the latter is intended, however, the court failed to indicate the criteria by which such a showing would be judged; and, consequently, since Dennis would be mapplicable, one seeking access is without any guides as to what he inust demonstrate.

Despite the purported acceptance of the reasoning of Dennis, ${ }^{113}$ Cargill gives insufficient deference to the fact that the Supreme Court found it necessary to consider the question of "particularized need" even though the defendants apparently sought the transcript for cross-examination purposes. ${ }^{114}$ While the support for an unlimited rule may thus be suspect, it is also questionable whether Dennis may properly be restricted solely to disclosure for use in cross-examination. The Dennis Court's quotation of the statement in Procter \& Gamble to the effect that use for inipeachment, refreshing, or credibility testing purposes are instances of "particularized need" was intended as merely illustrative of the modern trend toward hiberal disclosure. ${ }^{115}$ To the same end, the Court cited a decision allowing a private plaintiff to utilize grand jury testimony in maintaining his suit ${ }^{116}$ and, in discussing procedural alternatives, referred to disclosure for "impeachment

110381 F. 2d at 851-52.

111 While Youngblood referred to the use of the transcript for impeachment purposes as constituting a situation where disclosure is mandatory, 379 F. 2d at 369-70, the opinion does not indicate that automatic inspection is available only when such use is intended, id. Rather, disclosure is mandatory once a witness has appeared at trial. Id. The court in Cargill, in comparing its rule to that announced in Youngblood, expressiy noted that its own pronouncement was slightly less broad. 381 F. $2 \mathrm{~d}$ at 853 .

112 "The cases developing the rule announced in Dennis concern the use of testimony in cross-examination to impeach a wituess, to refresh his recollection, or to test his credibility. In Dennis the transcripts were sought for such purposes, and we consider that the opinion is implicitly so limited." 381 F. 2 d at 852-53.

11 Id. at 852.

${ }^{114}$ See Dennis v. United States, 384 U.S. 855, 872-73 (1966).

$115 \mathrm{Id}$. at $870-71$.

${ }^{110} I d$. at 870 n. 15 , citing Atlantic City Elec. Co. v. A. B. Chance Co., 313 F. $2 d$

431 (2d Cir. 1963). 
or other proper purposes."117 Nevertheless, despite these inconsistencies with Dennis, Cargill promulgates a rule approximating the benefits of the Youngblood decree both in clarity of availability and ease of administration. Yet, the Cargill pronouncement is perhaps potentially more acceptable to other courts since it is limited in scope and rests upon a construction of Dennis rather than solely upon judicial discretion.

The Court of Appeals for the Eighth Circuit, in National Dairy Products Corporation v. United States, ${ }^{118}$ rejected Cargill and Youngblood as overly broad, found Dennis to direct that where the prosecution has utilized the grand jury transcript during the trial, "particularized need" has been shown by that fact alone and the defendant may procure the portion of the transcript used as well as other segments relating to the same subject

${ }^{112} 384$ U.S. at 874. "Nor is it realistic to assume that the trial court's judgment as to the utility of material for impeachment or other legitimate purposes, however conscientiously made, would exhaust the possibilities." Id. at 874-75. Moreover, in light of the recent emphasis upon "fairness" in criminal cases, it is arguable that disclosure should not be limited to use in cross-examination. While the grand jury transcript may have impeachment value, it is also quite possible that it may contain evidence favorable to the defendant's case, in which situation disclosure may be necessary under the rule of Brady v. Maryland, 373 U. S. 83 (1963). See notes 152-58 infra and accompanying text.

${ }^{118} 384$ F.2d 457 (8th Cir. 1967), cert. denied, 390 U.S. 957 (1968). National Dairy was convicted in a criminal antitrust suit of violating the Sherman Act, 15 U.S.C. $\$ 1$ (1964). It appealed, alleging that the trial court erred in denying a request to inspect portions of the grand jury transcript used by the Government to refresh the inemory of certain prosecution witnesses. In an initial decision handed down before Dennis, the Eighth Circuit affirmed, National Dairy Prods. Corp. v. United States, 350 F. 2d 321 (8th Cir. 1965), but the Supreme Court vacated and remanded the case to the district court for reconsideration in light of Dennis, National Dairy Prods. Corp. v. United States, 384 U. S. 883 (1966). Again the trial court held against the defendant, and again the defendant appealed on the grounds that the denial was inconsistent with Dennis. On the second appeal, the Eighth Circuit reversed those counts in the indictment upon which the Government had presented evidence assisted by use of the transcript. National Dairy Prods. Corp. v. United States, 384 F. 2d 457 (8th Cir. 1967). Although the witnesses also gave testimony bearing on the issue of "intent" under the other counts, the court found these unaffected by the non-diselosure since there was substantial other evidence and the use of the transcript was of minimal aid with regard to the testimony on this issue. $1 d$. at 462 . Subsequently, the defendant petitioned the Supreme Court for certiorari a second time, alleging that the Eighth Circuit's interpretation of Dennis was incorrect because its effect would be to legitimitize non-disclosure despite demoustration of "partieularized need" if other evidence supported the verdict and the transcript was of little aid to the Government. 36 U.S.L.W. 3265 (U. S. Jan. 2, 1968) (No. 935); see BNA ANtitrust \& TrAde Reo. Rep. No. 338 , at A-2 to -3 (Jan. 2, 1968). Furthermore, National Dairy alleged that denial of access to the grand jury testimony deprived it of its rights under the fifth and sixth amendments by preventing effective cross-examination. BNA ANTITRUST \& TRADE Reo. REP. at A-3. However, the Supreme Court denied certiorari. National Dairy Prods. Corp. v. United States, — U. S. - (1968). 
matter. 119 Noting that Dennis had confirmed the discretion of trial courts under rule 6(e), 120 the court emphasized the quote in Dennis from Procter \& Gamble (121 $^{10}$ conclude that the effect of the decision was to restrict the discretionary power of the court to deny disclosure where the prosecution utilized the transcript to refresh the recollection of government witnesses or, apparently, for either of the other purposes stated in Procter \& Gamble. ${ }^{122}$ Thus, National Dairy promulgates a significantly different and more limited interpretation of Dennis than does Cargill: while Cargill would grant disclosure whenever requested by the defense for any of the three purposes, National Dairy finds "need" immediately satisficd only if the transcript is utilized by the Government during the trial.

Where the Government has not taken advantage of the grand jury testimony, the court construed Dennis to require that the existence of "particularized need" be determined according to the characteristics of each case and considered the function of Dennis to have been a demonstration of the fact that "need" may exist even where the transcript has not been utilized at trial.123 Thus, although the opinion is unclear, it would seem arguable that the court would adhere to the factor analysis outlined in Dennis to determine the presence of sufficient "circumstances" im those

119384 F. 2d at 460 . "We do not regard the holding in Dennis to require the practice adopted ... in Youngblood . . . . Neither do we subscribe to the concept that the defense is entitled to the grand jury transcript upon timely request irrespective of the circumstances involved which seems to be the rule ... in Cargill ...." Id. at 461 . The court did not attempt to distinguish either Youngblood or Cargill, but observed that, unlike the rules promulgated in those two decisions, the Eighth Circuit would adhere to the standard of "particularized need" in granting disclosure, as utilized in Dennis, by evaluating the circumstances of each individual case. Id. The court did not reveal the analysis which compelled its holding, nor is there textual support for the conclusion that Dennis "enunciat[ed] the proposition that where the district court permits the Government to use the grand jury transcript . . . a showing of particularized need has been inade ...." Id. at 460 . In the limited sense that this conclusion by the court is, in fact, within the Dennis rule, it is correct. However, the court assumes it is the only situation in which disclosure should be automatic.

120 Id. at 459.

121 Id. See notes 55 \& 115 supra and accompanying text.

122384 F. 2d at 459. There does not appear to be precedential support for the conclusion of the Eighth Circuit that the trial court's discretion should be limited only when the Government has utilized the transcript. Neither the unusual statement in United States v. Procter \& Gamble Co., 356 U. S. 677, 683 (1958), nor the quotation in Dennis v. United States, 384 U. S. 855,870 (1966), give any indication that the phrase "problems concerning the use of the grand jury transcript" refers only to its use by the Government. Moreover, the Government had not utilized the transcript at trial in Procter \& Gamble, but rather the litigation concerned a request for the grand jury testimony for pre-trial use in preparing the defense. United States v. Procter \& Gamble Co., supra at 678-79.

${ }^{123} 384$ F. $2 d$ at 460 . 
cases without the liberal rule. This contention is supported by the fact that the district court was reversed not because its application of the five factors present in Dennis to determine "need" was itself incorrect, but because the standard promulgated by Dennis "applicable to this case" had been misinterpreted. ${ }^{124}$ Thus, the effect of National Dairy is to grant to the prosecution an undue advantage in that it has within its discretion the means to effectively restrict the disclosure available to the defense.

Although the court clearly purported to base its rule upon Dennis, it is difficult to find any express support in that opinion for the position taken by the Eighth Circuit. Moreover, while the court notes Youngblood and Cargill as support for its views, those decisions do not give any determinative effect, nor even refer, to the prosecution's use of the grand jury transcript.125 On the other hand, Dennis also would not specifically preclude the National Dairy rule. While the court failed to indicate why its decision would not infringe upon valid reasons for secrecy, there would seen to be no difficulty since the transcript would not be divulged until the witness had appeared at trial. ${ }^{126}$ However, it unay be contended that National Dairy is inconsistent with the emphasis in Dennis upon the power of the trial court to determine disclosure under rule $6(\mathrm{e})^{127}$ since it grants to the prosecution the power to decide whether the defense will receive the transcript merely upon request or will be required to sustain the difficult burden, as shown by Osborne ${ }^{128}$ and Youngblood, ${ }^{129}$ of proving "particularized need" under a literal reading of Dennis. 130

It seems clear from the above decisions that the courts have been unable to derive froin Dennis a uniform interpretation of the requirements a defendant must meet to attain access to grand jury testimony. Rather, it would appear that Dennis has been utilized by each court to achieve what it considers the proper rule, a function to which Dennis is well suited by its ambiguity. ${ }^{131}$ Although no one of the decisions would be clearly overruled by Dennis, it is equally arguable that their rules gain no express support

124 Id. at 459 .

$125 \mathrm{Id}$. at 460.

${ }^{126}$ Once the witness has appeared at trial, the reasons for secrecy are no longer applicable. See note 46 supra.

${ }^{127}$ See note 16 supra.

${ }^{128}$ See notes 77-80 supra and accompanying text.

${ }^{129}$ Although Youngblood renounced the standard of "particularized need" as a requirement for gaining disclosure once a witness has testified at trial, 379 F. $2 \mathrm{~d}$ at 370, in the instant case the court applied the "five factors" test employed in Dennis, 384 U. S. at $872-73$, and held that as only two of the factors were present, denial of the defendant's request for disclosure was not improper. 379 F. 2 d at 368.

${ }^{130}$ Sce notes 77-80 supra and accompanying text.

${ }^{131}$ See notes 54-60 supra and accompanying text. 
from that opinion. On the other hand, all but Osborne ${ }^{132}$ are clearly compatible with the permissive tenor of the Dennis opinion and find in that attitude the primary justification for their promulgations. Consequently, the overall result has been to utilize the generalities of Dennis to significantly liberalize disclosure so that in most of the cases the defendant has at least one relatively unimpeded avenue to access, and in all cases the requirements he inust meet are markedly more distinct. Nevertheless, it should be noted that the standard of "particularized need," although denuded of substance in some circumstances, ${ }^{133}$ remaims a relevant term under all but the Allen decision, ${ }^{134}$ and the courts have apparently given the standard a restrictive interpretation based upon a literal readimg of Dennis in those situations where their expansive rules are inapplicable. ${ }^{135}$ The courts have, however, relegated the traditional secrecy justifications to a role consistent with the ends they are intended to serve and thereby have significantly alleviated the unfair prosecutorial advantage inherent in "exclusive access to a storehouse of relevant fact."136

Aside from the requisites of permissible disclosure, the Dennis opinion was also unclear regarding the procedures to be followed in making the grand jury transcript available to the defendant once the propriety of

132 Osborne v. United States, 371 F. 2d 913 (9th Cir.), cert. denied, 387 U. S. 946 (1967). See notes 77-80 supra and accompanying text.

${ }^{133}$ In United States v. Youngblood, 379 F. 2d 365 (2d Cir. 1967), demonstration of "particularized need" was declared unnecessary to gain disclosure once a witness had appeared at trial. Id. at 370. See note 106 supra \& notes 81-93 supra and accompanying text. Cargill v. United States, 381 F. $2 d 849$ (10th Cir. 1967), while maintaining the standard of "particularized need," effectively eliminated it where the request for the grand jury testimony was for use in cross-examination. Id. at 852-53. See notes 108-12 supra and accompanying text.

${ }^{134}$ Allen observed that in light of the trend toward more liberal disclosure, 'Dennis should be interpreted as lowering the minimum amount of need necessary to gain disclosure. $390 \mathrm{~F} .2 \mathrm{~d}$ at $481-82$. Thus, the court held that the defendant is entitled to inspection upon a showing of a "semblence of need." Id. However, aside from the inference that the new standard is less stringent than that of "particularized need," the court failed to define the term "semblence of need."

${ }_{135}$ See National Dairy Prods. Corp. v. United States, 384 F. 2d 457 (8th Cir. 1967), cert. denied, 390 U.S. 957 (1968); Cargill v. United States, 381 F.2d 849 (10th Cir. 1967); United States v. Youngblood, 379 F. 2d 365, 367-69 (2d Cir. 1967); Osborne v. United States, 371 F.2d 913, 919 (9th Cir.), cert. denied, 387 U.S. 946 (1967).

${ }^{130}$ Dennis v. United States, 384 U.S. 855, 873 (1966). The realization that the prosecution holds an unfair advantage if disclosure is wholly denied to a defendant is a conclusion inconsistent with the belief propounded by Judge Learned Hand in United States v. Garsson, 291 F. 646 (S.D.N.Y. 1923), that since "[u]nder our criminal proeedure the accused lias every advantage," inspection of grand jury minutes by a defendant should not be permitted. Id. at 649 . 
disclosure had been determined. 137 However, contrary to their conflicting views upon the requirements for access, the subsequent decisions have been relatively uniform in the proceedings adopted to transmit relevant portions of the transcript to the defense. Thus, four of the courts apparently agree that the defendant should reccive the relevant portions of the transcript directly upon request whenever that request falls withim the particular court's rule governing the availability of disclosure. ${ }^{138}$ Concomitantly, three courts provide that in camera inspection by the trial judge preceding delivery to the defendant is permissible only where necessary to determine if all or portions of the material should be withheld pursuant to a motion for a protective order by the Government. ${ }^{139}$ Both of these provisions seem clearly consistent with Dennis. ${ }^{140}$

Cargill is ambiguous concerning the availability of disclosure beyond the precise doctrine of that case and consequently fails to discuss the appropriate disclosure procedures in such circumstances, ${ }^{141}$ and it is questionable whether National Dairy considers an in camera inspection relevant under its holding. ${ }^{142}$ Nevertheless, the only decision which does not

${ }^{137}$ See notes 63-67 supra and accompanying text.

${ }^{138}$ See Worthy v. United States, 383 F. 2d 524, 525 (D. C. Cir. 1967) (per curiam); National Dairy Prods. Corp. v. United States, 384 F.2d 457.460 (8th Cir. 1967); Cargill v. United States. 381 F.2d 849, 852-53 (10th Cir. 1967); Unitcd States v. Youngblood, 379 F. 2d 365, 369 (2d Cir. 1967). In Worthy the issue was whether a denial of disclosure upon a demonstration of "particularized need" constituted reversible error, even though the defendant could not prove that prejudice had resulted from the denial. 383 F. $2 d$ at 525. The District of Columbia Circuit held, in light of Dennis, that disclosure could not be refused to a defendant showing the requisite need, even if the trial judge felt that no prejudicei would result from non-disclosure. Id. This holding, in conjunction with Allen v. United States, 390 F.2d 476 (D.C. Cir. 1968); notes 94-106 supra and accompanying text, clearly indicates that the District of Columbia Circuit may be counted among the courts which would provide direct disclosure once the iniposed prerequisite has been met.

${ }^{139}$ See, e.g., Allen v. United States, 390 F.2d 476, $481-82$ (D. C. Cir. 1968); Cargill v. United States, 381 F. 2d 849, 852 (10th Cir. 1967); United States v. Youngblood, 379 F. 2d 365, 370 (2d Cir. 1967).

${ }^{140}$ See notes 64-67 supra and accompanying text.

${ }^{141}$ The Tenth Circuit held explicitly that a defendant is entitled under the mandate of Dennis to disclosure as a matter of right without an in camera inspection if he seeks the testimony for cross-examination purposes. 381 F. $2 \mathrm{~d}$ at 852 . However, the court did not indicate the procedure to be followed for obtaining testimony souglit for some other purpose, but, rather, construed Dennis to apply only to the use of grand jury transcripts for cross-examination purposes. See note 112 supra and accoinpanying text. If under other circumstances the role of the trial judge is to inspect the transcript and eliminate "extraneous matter," then the judge would, contrary to Dennis, assume the role of the advocate, determining what is useful to the defendant's case. Dennis $v$. United States, 384 U.S. 855, 874-75 (1966).

142 "[W] are led to believe that in a case where, as here, the government is permitted at trial to use the grand jury transcript, the discretionary power of the district 
clearly recognize the propriety of direct access is Osborne. Concluding disclosure to have been correctly denied since "particularized need" as required by Dennis had not been shown, ${ }^{143}$ the Court of Appeals for the Ninth Circuit added merely that the trial judge "in an abundance of caution [might have granted] an in camera inspection appropriate when there is a showing of 'particularized need." "144 If this statenent indicates that a minimum showing of "particularized need" is necessary to obtaim any inspection, ${ }^{145}$ the court's position seems inconsistent with the admonition in Dennis that only an advocate can "properly and effectively" discern that which is useful to the defense. ${ }^{146}$ Nevertheless, it would appear that the ambiguity of Dennis regarding procedural mechanics has been primarily illusory and that a common approach is at least in the process of development.

The decisions in Allen, Cargill, National Dairy, Osborne, and Youngblood ultimately reveal an inherent weakness in the Dennis opinion. Resting its decision upon the flexible standard of "particularized need" and the discretionary powers of the trial judge under Federal Rule of Criminal Procedure 6(e), Dennis provides the courts with the means to promulgate widely varying delineations of both the scope of access available to the defendant and the burden which must be carried to accomplish disclosure. A nore uniform approach may be founded upon a constitutional basis.

Initially, it may be contended that the sixth amendinent ${ }^{147}$ right to confrontation provides grounds upon which a defendant may compel disclosure of grand jury testimony. This guarantee encompasses, and is

court to limit disclosure is restricted." $384 \mathrm{~F} .2 \mathrm{~d}$ at 459 . In a footnote to this statement, the court stated that although the Supreme Court had "recognized that in camera inspection by the trial judge may be useful for certain purposes, . . . that . . . by no means disposes of the matter." Id. at n.4. The court continued by quoting from Dennis to the effect that the judge's role in disclosure should be limited and that a proper determination of what is useful to the defendant can only be made by an advocate. Id. Since the court concluded that in the above situation the trial judge must grant disclosure, id. at 460 , an in camera inspection would seemingly be irrelevant since the court no longer may exercise any discretion, but must produce the requested testimony.

${ }_{143}$ Osborne v. United States, 371 F. 2d 913, 919 (9th Cir.), cert. denied, 387 U.S. 946 (1967). See notes 77-80 supra and accompanying text.

144371 F. $2 d$ at 919.

${ }^{145}$ The basis of the conclusion that the Ninth Circuit requires a showing of "particularized need" simply to obtain an in camera inspection of the requested portion of the grand jury testimony rests in the assumption that if direct disclosure were mandatory upon a showing of "particularized need" there would be no necessity for an in camera inspection, since the trial judge conld not deny disclosure. See note 138 supra.

${ }^{160}$ Dennis v. United States, 384 U.S. 855, 874-75 (1966).

${ }^{147}$ The sixth amendment provides that "in all criminal prosecutions, the accused shall enjoy the right ... to be confronted with the witness against him ...." 
primarily based upon, the right to an opportunity for effective cross-examination, including the opportunity to impeach the testimony given. ${ }^{148} \mathrm{~A}$ grand jury transcript may often include testimony of unquestioned impeachment value to the defense without which confrontation would be ineffective. Thus, to ensure the defendant the full potential of his opportunity for cross-examination, it is at least arguable that the sixth amendment should compell disclosure of relevant portions of a grand jury transcript. ${ }^{149}$ Since the testimony would not be available until after the witness has appeared at trial, traditional arguments for secrecy should be of minimal efficacy. ${ }^{150}$ Consequently, there would seem to be hittle difficulty in permitting the defendant to inspect relevant portions of the transcript upon request, subject only to a protective order. The resultant rule would approximate that in Youngblood, ${ }^{151}$ but, as constitutionally based, would receive cominon application. Moreover, if some form of regulation over the ultimate use of the transcript is considered necessary, it could be provided that the material nnay not be utilized at trial unless bona fide impeachment value is demonstrated to the trial judge. In this manner, the defendant's ability to effectively cross-examine would be maximized while the dangers of wholesale disclosure would still be avoided.

A broader scope of disclosure may be based upon considerations of due process under the fifth amendment. In Brady v. Maryland ${ }^{152}$ the Supreme

${ }^{148}$ See, e.g., Parker v. Gladden, 385 U.S. 363 (1966) (per curiam); Pointer v. Texas, 380 U.S. 400 (1965); Kirby v. United States, 174 U.S. 47 (1899); 5 J. WIGMORE, EVIDENCE \& 1397 (3d ed. 1940); McKay, The Right of Confrontation, 1959 WaSh. U. L. Q. 122, 123-26; Note, 44 N. C. L. Rev. 173, 175 (1965); Comment, 38 Texas L. Rev. 595, 609 (1960). In Kirby the Supreme Court considered the sixth amendment to require that facts establishable "only by witnesses cannot be proved against an accused . . . except by witnesses who confront him at the trial, . . . whom he is entitled to cross-examine, and whose testimony he may impeach in every mode authorized by the . . rules governing the trial . .."174 U.S. at 55. Moreover, in Dowdell v. United States, 221 U.S. 325 (1911), the Court, considering a statute modeled after the sixth amendment, held that the federal standard was "intended . . . particularly to preserve the right of the accused to test the recolleetion of the witness in the exercise of the right of cross-examination." Id. at 330.

${ }^{149}$ See notes 118 \& 148 supra; cf. Comment, 38 TeXas L. Rev. 595, 608-11 (1960). The right to confrontation may not be satisfied unless the accused has an opportunity for effective cross-examination. See Pointer v. Texas, 380 U. S. 400 (1965), noted in 44 N. C. L. REv. 173 (1965).

${ }^{150}$ See note 46 supra.

${ }^{151}$ See note 89 supra and accompanying text.

${ }^{163} 373$ U.S. 83 (1963). See also Miller v. Pate, 386 U.S. 1 (1967); Ashley v. Texas, 319 F.2d 80 (5th Cir.), cert. denied, 375 U.S. 931 (1963). See generally Comment, Disclosure and Discovery in Criminal Cases: Where Are We Headed?, 6 DuQuesne L. Rev. 41, 45-50 (1967); Note, The Prosecuting Attorney's Duty to Disclose, 6 WashBURN L. J. 479, 487-92 (1967); Comment, The Prosecutor's Constl- 
Court held that the failure of the prosecution to satisfy a request for material evidence favorable to the defendant was inconsistent with the requirements of due process since its effect was to lead to an unfair trial.153 Because grand jury testimony may be considered part of the evidence held by the prosecution ${ }^{154}$ and the Brady mandate is not limited to specific forms of evidence, that decision arguably should apply to such materials if they may contain "favorable" or "exculpatory" evidence. ${ }^{155}$ Apparently, the test which has emerged from Brady is whether the suppression handicaps the accused's ability to defend or inhibits the ultimate ascertainment of the truth. ${ }^{156}$ It seems likely that grand jury testimony would often include evidence which tends to prove the defendant's innocence and which markedly improves the quality of his defense. For example, the transcript may contain conflicting statements by different witnesses, the identity and statements of a witness favorable to the defense, or relevant inedical or psychiatric reports-the suppression of each of which has been found inconsistent with Brady. ${ }^{157}$ Moreover, if the concept of "materiality" utilized

tutional Duty to Reveal Evidence to the Defendant, 74 YALE L. J. 136, 142-50 (1964); Comment, 17 BaYLoR L. Rev. 400 (1965); Note, 19 OkLA. L. Rev. 425 (1966).

${ }^{153} 373$ U. S. at 87. See generally Comment, Disclosure and Discovery in Criminal Cases: Where Are We Headed?, 6 DuQuesne L. Rev. 41, 45-50 (1967). The Court stated: "We now hold that the suppression by the prosecution of evidence favorable to an accused upon request violates due process where the evidence is material either to guilt or to punishment, irrespective of the good faith or bad faith of the prosecution." 373 U. S. at 87. Whether the Court used "material" in its literal sense is unclear, for it is arguable that "favorable evidence" and "material evidence" are redundant. However, in the absence of any proof to the contrary, it would appear that "material" qualifies the nature of the favorable evidence.

${ }^{154}$ See Carter, Suppression of Evidence Favorable to an Accused, 34 F. R. D. 87, 87-88 (1964).

${ }^{155}$ See United States v. Cobb, 271 F. Supp. 159, 163-64 (S.D.N.Y. 1967). It has been observed that Brady "covers any evidence either tending to prove . . . innocence or . . . affect . . . punishment." Note, 19 OKLA. L. REv. 425, 426 (1966); cf. United States v. Westmoreland, 41 F.R.D. 419, 421-23 (S. D. Ind. 1967).

150 "In Brady . . . the Court made it clear that its primary interest was . . . to insure a fair trial to the defendant, and particularly to insure that the trial would bring out, not hide, the truth." Jackson v. Wainwright, - F.2d -, - (5th Cir. 1968). Consequently, "lower federal courts have emphasized the harm to the defendant . . . "Id.; accord, Barbee v. Warden, 331 F.2d 842 (4th Cir. 1964); Ashley v. Texas, 319 F.2d 80 (5th Cir.), cert. denied, 375 U.S. 931 (1963); see Comment, The Need for Liberalized Rules of Discovery in Criminal Procedure, 49 MARQ. L. Rev. 736, 742 (1966); Comment, The Prosecutor's Constitutional Duty to Reveal Evidence to the Defendant, 74. YALE L. J. 136, 142, 146-47 (1964); Note, 19 OKLA. L. ReV. 425, 426 (1966).

${ }^{257}$ See, e.g., Jackson v. Wainwright, 390 F.2d 288 (5th Cir. 1968) (suppression of statements of a witness favorable to the defense); Ashley v. Texas, 319 F.2d 80 (5th Cir.), cert. denied, 375 U.S. 931 (1963) (psychiatric reports revealing defendant's legal insanity withheld from defense counsel); United States ex rel. Thompson v. Dye, 
by Brady encompasses all information which will ultimately affect the determination of guilt or innocence, ${ }^{158}$ it would seem arguable that grand jury testimony of impeachment value should fall within the rule since the effect of impeachment will be to significantly destroy the efficacy of the prosecution's case.

It may also be contended that disclosure should be allowed prior to the trial since, as Brady and subsequent cases indicate, the fundamental question is whether the suppression caused an unfair trial because the accused was thereby doomed to an uninformed and madequate defense. ${ }^{159}$ Thus, the effect of the withheld material on the defendant's preparation for trial determines consistency with due process. Consequently, grand jury testimony should be available to the defendant when it would assist him in planning the course and nature of his defense. ${ }^{160}$ Relatedly, it would seem

221 F.2d 763 (3d Cir.), cert. denied, 350 U.S. 875 (1955) (suppression of witnesses whose testimony would conflict with that of prosecution's chief witness).

${ }^{158}$ It would seem overiy restrictive to limit the "material" evidence upon which Brady operates, 373 U. S. at 87, to direct, substantive evidence alone. Evidence to impeach or test credibility, although perhaps not substantive as to the issues involved, is material to the probity of the matters in issue. See C. MCCoRMICK, LAW of Evidence $\S 152$ (1954). Moreover, if Brady applies to any evidence tending to demonstrate guilt or innocence and is intended to insure that the trial will delimeate the truth, as would appear to be contemporary interpretation, see note 156 supra, then impeachment evidence should clearly be encompassed since its function is to separate falsity from validity, and may ultimateiy, in fact if not in form, influence the determination of guilt or innocence. See C. MCCoRMrck, supra, \$39. Finally, it is arguable that the Supreme Court includes impeachment or credibility evidence within the term "material" evidence. Thus, in Jencks v. United States, 353 U. S. 657 (1957), the Court, reversing a conviction because the trial court had refused a motion to compel the prosecution to produce previously reported statements of various witnesses, noted that a necessity of showing control between the reports and testimony would operate "to deny the accused evidence relevant and material to his defense," id. at 667 , and that the defendant could inspect the reports for ouly he could determine "the effective use for purpose of discrediting the Government's witness and thereby furthering [his] . . defense . . . " Id. at 668-69 (emphasis added).

${ }^{159}$ Although Brady has been interpreted to apply only to motions for disclosure made during the trial itself, see Carter, supra note 154 , at 88 , the more prevalent construction has been to emphasize that the real harm resulting to a defendant from nondisclosed evidence occurs before the trial since without the evidence the accused is unable to construct and plan an effective defense and therefore is denied a fair trial. See Jackson v. Wainwright, 390 F.2d 288 (5th Cir. 1968); United States ex rel. Meers v. Wilkins, 326 F.2d 135 (2d Cir. 1964); Ashley v. Texas, 319 F.2d 80 (5th Cir.), cert. denied, 375 U.S. 931 (1963); United States v. Cobb, 271 F. Supp. 159, 163-64 (S.D.N.Y. 1967); Comment, The Prosecutor's Constitutional Duty to Reveal Evidence to the Defendant, 74 YALE L.J. 136, 142-47 (1964).

${ }^{160}$ See United States v. Cobb, 271 F. Supp. 159 (S.D.N.Y. 1967). In Cobb the court recognized that grand jury testimony shonld be available to assist the defendant in constructing his defense, but also felt it necessary to limit the extent to which 
that the defendant may also be entitled to relevant unfavorable evidence since knowledge thereof is likely to aid the defendant in the structuring of his case almost as mucl as material tending to aid in the establishment of his innocence. 161

Granting that failure to disclose material relevant to the defense either during or prefatory to trial may constitute a denial of due process, the question remains whether the rule may properly be afforded unlimited application to grand jury testimony in hight of the unique characteristics of that material. Unlike other forms of evidence, grand jury transcripts remain validly protected, in some cases by the traditional necessities for secrecy. ${ }^{162}$ Yet, there would seein little difficulty in adapting the procedural rule promulgated in Dennis and accepted by the subsequent cases to limit the dangers of inopportune disclosure: 163 the defendant should be entitled to all relevant and useful portions of the transcript subject to the limitation of a protective order obtained by the Government upon the need for secrecy or other valid grounds. If a motion for such an order were made, the trial judge would examine the material in camera to determine the propriety of

the defense could exercise a "fishing expedition" into government files. Id. at 163-64. Consequently, the court held that the Government might fulfill its duty by disclosing to the defendant prior to trial, information which is obviously exculpatory and which would be of assistance in planning the defense, subject to the sanction of a mistrial if its disclosure was not adequate. Id. at 164; cf. United States v. Aeroquip Corp., 41 F.R.D. 441 (E.D. Mich. 1966).

${ }^{101}$ See Comment, The Prosecutor's Constitutional Duty to Reveal Evidence to the Defendant, 74 YALE L.J. 136, 147 (1964). As the author of this comment notes, if the evidence which coines under the aegis of the fifth amendment is limited to "exculpatory" evidence, the prosecution is placed in the position of determining the value of the materials to the defendant's case. Furthermore, if the material is "neutral," there is no "duty" to reveal it, and thus a defendant might be deprived of evidence around which he might build a stronger case, but which, alone, would not tend to show innocence. Id.

${ }^{162}$ For a list of the traditional rules of secrecy see text accompanying note 19 supra. Although these reasons may be valid during the grand jury proceedings, $c f$. United States v. Youngblood, 379 F.2d 365, 369-70 (2d Cir. 1967); United States v. Cobb, 271 F. Supp. 159, 163-64 (S.D.N.Y. 1967); Calkins, Grand Jury Secrecy, 63 MICH. L. REv. 455, 458-60 (1965), it would appear that once the indictment has issued the validity is lost. See United States v. Youngblood, supra at 370 n.3.

${ }^{103}$ See notes 137-40 supra and accompanying text. It may be contended that the Supreme Court has given tacit approval to pre-trial discovery of a grand jury transcript for nse in the preparation of the defendant's case. In United States v. Procter \& Gamble Co., 356 U.S. 677 (1958), the defendant requested the transcript to assist in the creation of his defense, since the Government had beeu able to utilize it to prepare the prosecution. Id. at 678-79. In refusing this request, the Court did not provide that the necessities of secrecy precluded pre-trial production, but held "only . . . that no compelling necessity [was] shown for the wholesale discovery and production of [the] ... transcript ...." Id. at 683 . Consequently, it would appear that the policy of secrecy does not automatically prevent pre-trial disclosure. 
disclosure. Certainly the prosecutor should not play the determinative role in the assessment of a claim for suppression, but rather he should be required to reveal all pertinent information. Less consistent with the argument that only the defendant appropriately determines what is useful to his case would be a rule that the trial judge determine usefulness prior to revealing the information to the defense, although such a procedure burdens the judge with the advocate's role. 164 Another alternative might be to require the Government to furmish those portions of the transcript which are clcarly useful but permit it to deny disclosure where the value of the Inaterial sought is doubtful, subject to declaration of a mistrial if the judge finds the prosecutor's choice to be arbitrary. ${ }^{165}$ In any event, it would appear that viable governing rules could be developed by which the defendant's due process guarantee of a fair trial could be effectively realized while those aspects of secrecy necessarily accorded grand jury testimony are preserved.

\section{CONCLUSION}

The proposed constitutional standards would provide beneficial clarification and uniformity as to both the availability of disclosure in each federal jurisdiction and the scope of access permitted. Not only would the defendant's right to view the transcript upon request be established but it would also be resolved that the testimony could be utilized for purposes other than merely cross-examination. A constitutional standard would not, however, be devoid of disabilities. For example, it is possible that a relatively unimpeded right of access would be abused by defendants who sought disclosure solely to effectuate a delay, to coerce or improperly influence witnesses, or to gain access to information not of major significance to the defense but which would otherwise have been necessary to procure by unilateral efforts. It would seein likely, however, that the judiciary could develop sanctions by which such abuse would be discouraged. Although an attractive means of accomplishing this end may be to require a demonstration of bona fides or some "semblance of need," the proven difficulties of adequately defining and administering such a prerequisite would produce the same ambiguity which tortures present disclosure rules. Consequently, it wonld be preferable to retain a liberal initial standard and endeavor to preclude improper motivation by the deterrence of post-request procedures.

${ }^{164}$ See Comment, The Prosecutor's Constitutional Duty to Reveal Evidence to the Defendant, 74 YALE L.J. 136, 148 (1964). See also Dennis v. United States, 384 U.S. 855, 874-75 (1966); Herzog v. United States, 226 F.2d 561, 567 (9th Cir. 1955), aff'd en banc, 235 F.2d 664, cert. denied, 352 U.S. 844 (1956); Calkins, Grand Jury Secrecy, 63 Mich. L. Rev. 455, 478-81 (1965). 160 supra.

${ }^{165}$ See United States v. Cobb, 271 F. Supp. 159, 164 (S.D.N.Y. 1967); note 
A constitutionally based disclosure standard may also entail an increased financial burden upon criminal administration by requiring, unlike present practice, that grand jury testimony be consistently recorded. Such a rule may be compelled by the contention that equal protection of the laws is denied a defendant who is unable to utilize a grand jury transcript in the preparation and presentation of his defense merely because the jurisdiction in which he is indicted does not require recordation. ${ }^{166}$. Uniform transcription requirements might also ensue from the potential ability in the government prosecutor to avoid the operation of the standard in his jurisdiction by persuading the judicial administration to cease recordation or by indicting the multi-jurisdictional defendant, such as the corporate defendant in a typical antitrust suit, in a district where testimony is unrecorded. It may be further noted that potentially increased administrative expense has not inhibited the adoption of other protections, such as mandatory counsel or trial transcripts, for indigent defendants.

In sum, given the significant benefits of facile administration, clarity and predictability of application, and uniformity redounding from a constitutional standard for determining disclosure of grand jury transcripts, the dangers of abuse and the cost of transcription seem but a small price exacted for the assurance of a competent defense and a fair trial for the criminal defendant.

${ }^{160}$ The Supreme Court has incorporated, at least in part, the concept of equal protection into the due process clause of the fifth amendment. See Bolling v. Sharpe, 347 U.S. 497, 499 (1954). 